\title{
Pengaruh Aktivitas Antropogenik Terhadap Kualitas Air, Sedimen dan Moluska di Danau Maninjau, Sumatera Barat.
}

\author{
Muhamad Suhaemi Syawal $^{1 *}$, Yusli Wardiatno ${ }^{2}$, Sigid Hariyadi ${ }^{2}$ \\ ${ }^{1}$ Program Studi Pengelolaan Sumber Daya Perairan, Sekolah Pascasarjana, Institut Pertanian Bogor, \\ Kampus \\ IPB Dramaga, Bogor 16680. ${ }^{2}$ Departemen Manajemen Sumber Daya Perairan, Fakultas Perikanan dan Ilmu \\ Kelautan, Institut Pertanian Bogor, Kampus IPB Dramaga, Bogor 16680. \\ E-mail: syawalms@gmail.com
}

\begin{abstract}
ABSTRAK
Telah dilakukan penelitian dengan tujuan untuk mengkaji pengaruh pencemaran dari lingkungan antropogenik terhadap kondisi kualitas air, sedimen dan moluska di perairan Danau Maninjau. Danau Maninjau adalah salah satu danau yang terletak di Kabupaten Agam Sumatera Barat. Tipe danau ini adalah danau tekno vulkanik yang terbentuk oleh aktivitas vulkanik. Isu pencemaran air danau merupakan isu utama dalam pemanfaatan dan pengembangan kawasan danau, di daerah manapun. Kegiatan penduduk di sekitar danau yang cenderung bersifat produktif pada umumnya otomatis menghasilkan limbah buangan hasil proses produksi. Penelitian ini dilakukan selama 3 (tiga) kali dari bulan Maret-September 2015 di 7 (tujuh) titik lokasi muara sungai di sekitar D. Maninjau yang berpotensi masuknya bahan pencemar. Hasil yang diperoleh menunjukkan konsentrasi rata-rata TP pada air berkisar 0,0245-0,2117 mg L${ }^{-1}$; TN 0,5085-1,2292 mg L${ }^{-1}$; O-PO ${ }_{4} 0,0206-0,2241 \mathrm{mg} \mathrm{L}^{-1}$ dan $\mathrm{NO}_{3}$ 0,0841-1,0618 mg L-1. Kandungan logam rata-rata pada sedimen $\mathrm{Fe} 1,1733-3,5733 \mathrm{mg} \mathrm{kg}^{-1} ; \mathrm{Pb}$ 0,0037-11,230 mg kg-1 Cd 0,0050-0,0193 mg kg-1; Hg 0,00056-0,05914 mg kg-1; dan Cr tidak terdeteksi atau dibawah $0,004 \mathrm{mg} \mathrm{kg}^{-1}$. Sementara untuk rata-rata logam berat pada moluska Fe $0,04-$ $0,948 \mathrm{mg} \mathrm{kg}{ }^{-1}$; Pb 0,002-4,17 mg kg-1 $\mathrm{Cd} 0,013-1,032 \mathrm{mg} \mathrm{kg}^{-1}$; Cr 0,040-0,098 mg kg $0,0004-0,1062 \mathrm{mg} \mathrm{kg}^{-1}$. Dari hasil analisis data yang diperoleh menunjukkan ada dugaan telah terjadi pencemaran logam berat pada sedimen dan moluska di muara-muara sungai yang masuk langsung ke badan perairan Danau Maninjau.
\end{abstract}

Kata kunci :antropogenik, danau maninjau,kualitas air, moluska, sedimen,

\begin{abstract}
Has conducted research with the aim to study the effect of anthropogenic pollution of the environment on the condition of water quality, sediment and molluses in the waters of Lake Maninjau. Maninjau is one lake located in Agam regency of West Sumatra.Type this lake is techno volcaniclake formed by volcanic activity.The issue of pollution of the lake water is a major issue in the utilization and development of the area of the lake, in any area. Activity of the population around the lake tends to be productive in general automatically generates waste from the production process results. This study was conducted over three (3) times from March-September 2015 in seven (7) locations of river estuaries around D. Maninjau potential influx of contaminants.The results showed the average concentration of TP in water ranging from 0.0245 to $0.2117 \mathrm{mg} \mathrm{L}^{-1}$; TN 0.5085 to $1.2292 \mathrm{mg} \mathrm{L}^{-1}$; O$\mathrm{PO}_{4}$ from 0.0206 to $0.2241 \mathrm{mg} \mathrm{L}^{-1}$ and $\mathrm{NO}_{3} 0.0841$ to $1.0618 \mathrm{mg} \mathrm{L}^{-1}$. The average metal content in the sediment Fe 1.1733 to $3.5733 \mathrm{mg} \mathrm{kg}^{-1}$; $\mathrm{Pb} 0.0037$ to $11.230 \mathrm{mg} \mathrm{kg}^{-1}$; $\mathrm{Cd} 0.0050$ to $0.0193 \mathrm{mg} \mathrm{kg}^{-1}$; 0.00056 to $0.05914 \mathrm{mg} \mathrm{Hg} \mathrm{kg}$; ; and $\mathrm{Cr}$ undetectable or below $0.004 \mathrm{mg} \mathrm{kg}^{-1}$. As for the average heavy metals in mollusks Fe 0.04 to $0.948 \mathrm{mg} \mathrm{kg}^{-1} ; \mathrm{Pb} 0.002$ to $4.17 \mathrm{mg} \mathrm{kg}^{-1} ; \mathrm{Cd} 0.013$ to $1.032 \mathrm{mg}$ $\mathrm{kg}^{-1}$; Cr 0.040 to $0.098 \mathrm{mg} \mathrm{kg}^{-1}$; and $\mathrm{Hg}$ from 0.0004 to $0.1062 \mathrm{mg} \mathrm{kg}^{-1}$. From the analysis of the data obtained showed no allegation has been going on heavy metal pollution in the sediment and molluscs in a river estuary that goes directly into the water body of Lake Maninjau. The purpose of this study was to examine the influence of anthropogenic pollution of the environment on the condition of water quality, sediment and molluscs in the waters of Lake Maninjau
\end{abstract}

Keywords: anthropogenic, Lake Maninjau, molluscs, sediment, water quality 


\section{PENDAHULUAN}

Danau Maninjau adalah salah satu danau yang terletak di Kabupaten Agam Sumatera Barat. Tipe danau ini adalah danau tekto vulkanik yang terbentuk oleh aktivitas vulkanik. Danau Maninjau merupakan salah satu danau dari 15 danau prioritas di Indonesia yang memiliki berbagai fungsi yang sangat strategis dan menguntungkan bagi masyarakat disekitar danau yaitu sebagai pembangkit listrik tenaga air, pariwisata, sumber air irigasi serta kegiatan sektor perikanan yang sangat meningkat dari tahun ke tahun (Suwanto et al. 2011). Di kawasan D. Maninjau terdapat 88 buah sungai besar dan kecil dengan lebar maksimum 8 meter yang mengalir disepanjang daerah aliran sungai(DAS) dan bermuara ke danau. Kebanyakan dari sungai tersebut $(61,4 \%)$ kering pada waktu musim kemarau, sedangkan sungai-sungai yang berair sepanjang tahun hanya 34 buah sungai yang mengalir dengan debit yang relatif kecil (Fakhrudin et al. 2002).

Tingginya aktivitas di sekitar danau serta yang terjadi di perairan danau, merupakan sumber masukan bahan pencemar utama yang perlu memperoleh perhatian dari berbagai pihak. Hal ini disebabkan beragamnya sumber bahan pencemar tersebut masuk kedalam periran danau tanpa dapat terakumulasi di dalam danau. Sumber bahan pencemar tersebut antara lain berasal dari kegiatan masyarakat di sekitar hulu sungai, dari permukiman dan dari kegiatan yang berlangsung di badan perairan danau itu sendiri. Jenis bahan pencemar utama yang masuk ke perairan danau terdiri dari limbah organik, residu pestisida, anorganik dan bahan-bahan lainnya yang secara cepat atau lambat masuk ke badan perairan danau yang akan terendap pada sedimen yang tentunya akan mencemari perairan dan hewan bentik danau tersebut (Kumurur 2002).

Metcalf dan Eddy (2002) menambahkan air buangan tersebut berasal dari air yang digunakan pada berbagai kegiatan manusia sehingga terdapat perubahan karakteristik air. Rump (1999) menerangkan lebih lanjut bahwa perubahan karakteristik tersebut berupa perubahan komposisi air setelah digunakan oleh manusia. Perubahan komposisi tersebut akibat masuknya substansi unsur yang langsung dapat terdegradasi, unsur yang tidak langsung dapat terdegradasi, nutrisi untuk organisme autotrof, logam berat, garam, air buangan panas dan organisme patogen. Unsur-unsur tersebut bila masuk ke badan air dapat memberikan pengaruh pada kehidupan organisme akuatik dan manusia, sehingga kehidupan organisme dan manusia terganggu.Disamping itu berbagai aktivitas penduduk yang ada di sempadan danau, seperti permukiman, perhotelan, pertanian dan peternakan merupakan sumber bahan pencemar yang masuk ke perairan danau. Kegiatan di badan perairan danau, berupa pembudidayaan ikan dengan teknik keramba jaring apung (KJA) juga merupakan sumber limbah yang potensial mencemari perairan danau. Pengaruh tersebut diakibatkan oleh limbah pakan dan bahan pemberantas hama perikanan. Bila hal ini dilakukan terus menerus hingga konsentrasinya melebihi ambang batas, tidak diragukan lagi akan mencemari dan meracuni biota di perairan danau tersebut.

Keberadaan bahan pencemar tersebut dapat menyebabkan terjadinya penurunan kualitas perairan danau, sehingga tidak sesuai lagi dengan jenis peruntukannya sebagai sumber air baku air minum, perikanan, pariwisata dan sebagainya. Selain itu, tingginya masukan bahan pencemar dari atropogenik dapat menyebabkan hilangnya keanekaragaman hayati, khususnya spesies endemik danau tersebut (Kumurur, 2002). Nilai penting lainnya dari keberadaan D. Maninjau adalah adanya jenis ikan endemik, yakni ikan bada (Rasbora argyrotaenia) yang mempunyai nilai ekonomis yang tinggi. Keberadaan ikan-ikan tersebut diduga sudah semakin terancam akibat 
meningkatnya beban pencemaran yang masuk ke badan air danau, sehingga menyebabkan kualitas perairan danau semakin menurun. Pencemaran perairan danau tidak hanya dapat menimbulkan kerugian secara ekonomis dan ekologis berupa penurunan produktivitas hayati perairan, tetapi juga dapat membahayakan kesehatan bahkan lambat laun dapat menyebabkan kematian manusia yang memanfaatkan perairan danau untuk memenuhi kebutuhan hidupnya. Tujuan dari penelitian ini adalah untuk mengkaji pengaruh pencemaran dari lingkungan antropogenik di perairan Danau Maninjau

\section{METODE PENELITIAN}

Danau Maninjau secara administrasi termasuk ke dalam wilayah Kecamatan Tanjung Raya Kabupaten Agam, Secara geografis wilayah ini terletak pada $00^{\circ} 17^{\prime}-07.04$ ' $\mathrm{LS}$ dan $100^{\circ}$ - 09'58.0" BT dengan ketinggian 461,5 meter di atas permukaan laut. Proses terbentuknya Danau Maninjau merupakan danau vulkanis, yaitu berasal dari letusan gunung berapi.Arah bagian selatan danau, kedalaman semakin tinggi dengan lereng (slope) yang semakin curam. Pengambilan contoh air, sedimen dan moluska serta pengukuran kualitas air dilakukan selama 3 (tiga) kali dari bulan Maret-September 2015 di 7 (tujuh) titik lokasi muara sungai-sungai di sekitar Danau Maninjau yang berpotensi masuknya bahan pencemar dari antropogenik (Gambar 1 dan Tabel 1).

Pengukuran langsung dilapangan meliputi suhu, oksigen terlarut (DO), konduktivitas, turbiditas dan total dissolved solid (TDS) dengan menggunakan alat Water Quality CheckerHoriba U 20. Contoh air untuk parameter total fosfat (TP), total nitrogen (TN), ortofosfat $\left(\mathrm{O}-\mathrm{PO}_{4}\right)$, dan nitrat $\left(\mathrm{NO}_{3}\right)$ diambil sebanyak $250 \mathrm{ml}$ dan disimpan pada suhu $4^{\circ} \mathrm{C}$. Contoh air untuk parameter logam berat besi $(\mathrm{Fe})$, timbal $(\mathrm{Pb})$, kadmium (Cd), total khromium (T-Cr) dan total merkuri (T-Hg) dimasukkan kedalam botol gelas yang diawetkan dengan menambahkan asam sulfat $\left(\mathrm{H}_{2} \mathrm{SO}_{4}\right)$ hingga $\mathrm{pH}$ 2. Sedimen permukaan diambil menggunakan Ekman grab sampler sebanyak \pm 1500 gram berat basah dan dimasukan ke dalam kantong plastik untuk selanjutnya dikeringkan dalam oven $30^{\circ} \mathrm{C}$ untuk selanjutnya dianalisis konsentrasi logam beratnya. Contoh moluska diambil menggunakan Ekman grab dan dipisahkan dari sedimen yang selanjutnya diidentifikasi jenisnya dan disimpan didalam wadah yang sudah diberi formalin $5 \%$ atau alkohol $10 \%$. Kemudian diambil seluruh isi bagian dalam dari masingmasing jenis moluska tersebut dan dikeringkan menggunakan oven pada suhu $30{ }^{\circ} \mathrm{C}$. Jenis moluska yang dianalisi adalah moluska yang mempunyai nilai ekonomis atau sering dikonsumsi oleh masyarakat setempat, seperti (Corbicula moltkiana, Prime 1878, Melanoides sp. dan Bivalvia violacea) yang dalam bahasa lokal biasa disebut Pensi, Langkitang dan lokan). Seluruh kegiatan analisis contoh dilakukan di Laboratorium Hidrokimia, Pusat Penelitian Limnologi-LIPI Cibinong berdasarkan metode standar dari APHAAWWA (2012).

\section{HASIL DAN PEMBAHASAN}

\subsection{Distribusi nilai Kualitas Air}

Hasil pengukuran kualitas air dilapangan menunjukkan bahwa rata-rata pengukuran suhu air berkisar antara 21,03 $-23,26{ }^{\circ} \mathrm{C}$. Suhu terendah terdapat di St 6 (Pandan) dan tertinggi di St. 1 (Mukomuko) dan nilai range tertinggi terdapat pada St. 3 (Muaro Talao). Kisaran suhu air tersebut bersifat normal untuk kehidupan hewan atau moluska air tawar. Suhu merupakan faktor penting yang mempengaruhi kehidupan hewan-hewan air termasuk moluska. Tingkat respirasi akan semakin menurun seiring dengan peningkatan nilai kekeruhan dan konduktivitas. 
Nilai derajat keasaman $(\mathrm{pH})$ dapat mempengaruhi spesiasi senyawa kimia dan toksisitas dari unsur-unsur renik yang terdapat di perairan, sebagai contoh $\mathrm{H}_{2} \mathrm{~S}$ yang bersifat toksik banyak ditemui di perairan tercemar dan perairan dengan nilai $\mathrm{pH}$ rendah. Selain itu, $\mathrm{pH}$ juga mempengaruhi nilai Oksigen, fosfat, nitrogen dan nutrien lainnya (Dojildo \& Best, 1992). Pada penelitian ini nilai $\mathrm{pH}$ yang diperoleh berkisar 7,44-8,69. Nilai $\mathrm{pH}$ terendah terdapat di St. 1 (Mukomuko) dan tertinggi di St. 2 (Talao Tubo). Nilai range tertinggi untuk $\mathrm{pH}$ terdapat pada St. 5 (Bayur) (Tabel 2). Pada umumnya hewan bentik dan moluska dapat hidup pada $\mathrm{pH}$ yang berkisar 5,7 8,4 . Tidak terdapat perbedaan yang besar pada masing-masing stasiun pengamatan. Hal ini menunjukkan bahwa $\mathrm{pH}$ di muara sungai D. Maninjau masih memenuhi baku mutu untuk kehidupan biota yang berada didalam perairan tersebut.

Namun apabila pada perairan tawar nilai $\mathrm{pH}$ dibawah 5 maka kondisi hewan bentik termasuk moluska secara bertahap dapat kehilangan bobot hingga sampai ke kematian. Sementara menurut Cahyono (2000) ikan nila dapat hidup normal pada nilai $\mathrm{pH}$ berkisar $6-8,5$. Nilai Turbiditas atau kekeruhan pada saat pengukuran langsung dilapangan menunjukkan nilai berkisar 65.4- 326 NTU. Nilai turbiditas terendah terdapat di St. 5 (Bayur) dan tertinggi di St 7 (Pandan). Nilai range tertinggi untuk Turbiditas terdapat pada St. 7 (Pandan) dan nilai range terendah pada St. 2 (Talao Tubo) (Tabel 2). Hal ini diduga karena pada lokasi di St. 7 (Pandan) tingginya aktifitas masyarakat di hulu sungai, seperti pertanian dan aktifitas masyarakat di sempadan sungai yang sering digunakan sebagai tempat pembuangan sampah dan juga perbengkelan.

Kekeruhan yang terjadi pada perairan tergenang seperti danau lebih banyak disebabkan oleh bahan tersuspensi berupa koloid dan parikel-partikel halus. Kekeruhan yang tinggi dapat mengakibatkan terganggunnya sistem osmeregulasi seperti pernafasan dan daya lihat organisme akuatik serta dapat menghambat penetrasi cahaya ke dalam air. Menurut Koesoebiono (1979), pengaruh kekeruhan yang utama adalah penurunan penetrasi cahaya secara mencolok, sehingga aktivitas fotosintesis fitoplankton dan alga menurun, akibatnya produktivitas perairan menjadi turun.

Hasil keragaman nilai terhadap kualitas air dapat dilihat pada Tabel 4. Nilai yang memiliki keragaman terbesar adalah suhu air dengan nilai range sebesar 3,04 yang berarti bahwa suhu air memiliki nilai yang berubah-ubah cukup tinggi pada setiap lokasi. Hal ini diduga disebabkan oleh faktor waktu pengambilan contoh yang tidak seragam atau bersamaan waktunya. Suhu air, untuk setiap stasiun cendrung tidak terjadi variasi yang signifikan (suhu rata 22,02 \pm 1.19). Artinya secara spasial variasi suhu tidak terlihat signifikan. Walaupun suhu tidak bervariasi secara signifikan untuk setiap stasiun, akan tetapi suhu total yang ditunjukkan cukup dingin. Hal ini dapat merujuk adanya potensi D. Maninjau dapat mengalami Upwellingyangdidasari pada dugaan kondisi permukaan air yang cukup dingin dibandingkan bagian dalam air sehingga arus dalam air menjadi aktif. Resiko dari kejadian ini yakni perairan mengalami pencampuran yang membawa material beracun yang berasal dari bawah badan air. Derajat keasaman $(\mathrm{pH})$ yang tinggi ditunjukkan pada St. 2 (Talao Tubo) yang mengarah pada suasana basa. Kasus pH air menjadi basa di suatu perairan sangat berkaitan pada Bahan-bahan deterjen yang mengandung gugus Hidroksil. Gugus hidroksil $(\mathrm{OH})$ di perairan merupakan bahan hasil penyabunan dari limbah domestik disekitarnya. Situasi ini cukup berkorelatif terhadap pemukiman di Talao Tubo yang tinggi.

Daerah Pandan (St. 7) mewakili kondisi terpaparnya bahan organik yang tinggi hal ini terlihat pada nilai ORP 
$(202,33 \pm 14,22)$, konduktivitas $(0,03 \pm$ $0.002)$, turbiditas $(326,4 \pm 178,85)$ dan TDS $(22 \pm 1)$. Dasar paparan organik di perairan teridentifikasi pada ORP tinggi kemudian disusul dengan tingkat konduktivitas perairan yang rendah. Hal ini sangat logis karena materi organik menghambat hantaran transportasi elektron pada mineral yang ada di air sehingga kecendrungannya adalah perairan bersifat non polar. Cemaran bahan organik tinggi juga didukung oleh total padatan terlarut (TDS) yang rendah dan mengansumsi mineral yang terlarut mengalami pengendapan atau membentuk koloid. Bukti adanya hal tersebut juga didukung oleh turbiditas atau kekeruhan tinggi $(326,4 \pm 178,85)$. Gejala adanya cemaran organik tinggi di daerah ini bisa direferensikan bahwa lokasi ini memiliki aktivitas umum seperti pasar dan sekaligus menjadi pusat pemukiman. Kondisi oksigen terlarut sebenarnya menggambarkan di seluruh lokasi masih cukup baik dengan rata total DO (7.67 \pm 0.66 ) dan variasi tidak terlalu tinggi (Tabel 2).

\subsection{Distribusi konsentrasi Nitrat, Total Nitrogen, Ortofosfat dan Total Phospat}

Konsentrasi nitrit di perairan biasanya berada dalam konsentrasi relatif kecil, bila dibandingkan dengan senyawaan nitrogen lainnya. Keadaan ini dikarenakan senyawaan nitrit berada pada fase pertengahan proses nitrifikasi, denitrifikasi dan asimilasi Dari beberapa hasil penelitian sebelumnya diketahui konsentrasi nitrit pada Danau Maninjau sangat kecil bahkan cenderung tidak terdeteksi, sehingga pada penelitian ini analisis nitrit tidak dilakukan.

Konsentrasi nitrat tersebar merata disetiap lokasi namun memiliki nilai yang paling variatif (Gambar 2). Kisaran nitrat di muara-muara sungai Danau Maninjau adalah antara $0,0841-1,0618 \mathrm{mg} \mathrm{L}^{-1}$. Konsentrasi tertinggi pada St. 5 (Bayur) dan terendah terlihat pada St. 1 (Mukomuko). Walaupun rata-rata konsentrasi tersebut berada di bawah kisaran ambang batas yang dianjurkan untuk pengelolaan budidaya perairan (Meade, 1989), tetapi konsentrasi tersebut dapat menaikkan pertumbuhan sel-sel alga diperairan misalnya Ankistrodesmus convulutus yang berdasarkan hasil penelitian Chrismada (1998) dapat meningkat pertumbuhannya dengan kenaikan konsentrasi nitrat sampai $0,036 \mathrm{mg} \mathrm{N}-\mathrm{NO}_{3} \mathrm{mg} \mathrm{L}^{-1}$. Oleh karena itu dengan adanya konsentrasi nitrat tersebut dapat diidentifikasikan bahwa perairan tersebut menyediakan unsur hara yang siap diasimilasi oleh tumbuhan-tumbuhan akuatik(Hendersend-Selers \& Markland, 1987).

Konsentrasi total nitrogen (TN) menunjukkan bahwa cukup banyak nutrient-nutrien dari sungai yang terbawa masuk ke dalam badan Danau Maninjau tersebut, hal inilah sebagai salah satu masukan nutrient sehingga Danau Maninjau dikatagorikan dalam danau eutrofik. JØrgensen (1980) telah mengklasifikasi status trofik berdasarkan nilai konsentrasi TN. Konsentrasi TN yang berada dalam kisaran 0,5-1,1 $\mathrm{mg} \mathrm{L}^{-1}$ adalah merupakan konsentrasi $\mathrm{TN}$ di danau yang bersifat eutrofik. Tingginya konsentrasi TN di perairan akan menyebabkan peningkatan aktivitas mikroorganisme heterotrofik dalam mendekomposisinya menjadi senyawaan yang larut. Oleh karena itu akan terjadi produktivitas yang tinggi di permukaan karena terjadi pertumbuhan bakteri dan fungi yang melimpah (Rheinheimer, 1985).

Distribusi total fosfat (TP) di setiap stasiun hampir sama dengan distribusi O$\mathrm{PO}_{4}$ tetapi konsentrasinya lebih besar. Tingginya konsentrasi fosfat karena lokasi St. 6 (Muaro Pisang) tersebut berada di daerah pemukiman yang berpenduduk cukup padat yang secara langsung membuang limbah domestiknya ke sungai. Disamping aktifitas pertanian dibagian hulu sungai yang juga memberi kontribusi cukup tinggi akan kenaikan konsentrasi total fosfat. JØrgensen

(1980) 
mengklasifikasi status trofik suatu danau berdasarkan nilai konsentrasi TP nya, bila konsentrasi TP suatu danau berada dalam kisaran 0,010-0,030 mg TP/L. Berdasarkan hasil analisis konsentrasi TP dan TN, maka Danau Maninjau sudah termasuk kedalam danau eutrofik, dengan demikian ketersediaan unsur hara baik senyawaan nitrogen dan fosfat sudah lebih dari cukup bagi pertumbuhan organisma akuatik seperti plankton-plankton dan tumbuhan air.

Nitrogen dan fosfat yang terbawa menuju air permukaan menyebabkan eutrofikasi pada danau, sungai, dan perairan dangkal. Penggunaan limbah organik sebagai pupuk, seperti rabuk (pupuk kandang) dan lumpur pembuangan (sewage sludge), juga menyebabkan akumulasi logam berat dalam tanah. Pestisida, herbisida, dan senyawa agrokimia lainnya (khususnya jenis organoklorin) terbawa angin atau air, dapat menyebabkan peningkatan konsentrasi zat beracun dalam air permukaan dan tanah J Ørgensen (1980).

\subsection{Distribusi konsentrasi logam berat Besi, Timbal, Kadmium, Khromium dan Merkuri di sedimen}

Hasil analisis logam berat pada sedimen (Gambar 3) menunjukkan konsentrasi logam berat yang tidak merata pada setiap stasiunnya. Konsentrasi logam kadmium (Cd) dan Khrom (Cr) pada sedimen tidak terdeteksi atau dibawah limit deteksi dari alat yang digunakan AAS). Konsentrasi logam besi (Fe) pada sedimen tersebar merata di setiap stasiun dengan konsentrasi berkisar 1,173 - 3,573 $\mathrm{mg} \mathrm{kg}^{-1}$. Konsentrasi tertinggi terdapat di St. 1 (Muko-muko) dan terendah pada St. 5 (Bayur). Konsentrasi tertinggi pada lokasi Muko-muko ini diduga karena tingginya aktifitas penduduk disekitar sungai serta diduga ada pengaruh dari pertanian atau perkebunan.

Logam berat mempunyai sifat yang mudah mengikat bahan organik dan mengendap di dasar perairan dan bersatu dengan sedimen sehingga kadar logam berat dalam sedimen lebih tinggi dibandingkan dalam air (Walukow 2008). Sumber utama pemasukan logam menurut Wittman (1983) dalamConnel dan Miller (1995) adalah berasal dari kegiatan pertambangan, cairan limbah rumah tangga, limbah dan buangan industri serta aliran dari pertanian. Logam berat biasanya ditemukan sangat sedikit dalam air secara alamiah, yaitu kurang dari 1 $\mathrm{g} / \mathrm{L}$. Beberapa macam logam biasanya lebih dominan daripada logam lainnya dan dalam air biasanya tergantung pada asal sumber air (air tanah dan air sungai). Disamping itu jenis air (air tawar, air payau dan air laut) juga mempengaruhi kandungan logam di dalamnya (Darmono 2001).

Konsentrasi timbal $(\mathrm{Pb})$ umumnya terihat tinggi di empat stasiun yang berkisar $0,0037-11,230 \mathrm{mg} \mathrm{kg}^{-1}$. Konsentrasi tertinggi terlihat pada St. 6 (Muaro Pisang) dan terendah pada St. 4 (Muaro Tanjung). Konsentrasi timbal tertinggi dan yang umumnya terdapat pada setiap stasiun diduga karena ada aktifitas penduduk disekitar sungai yang melakukan kegiatan perbengkelan serta pertanian, dimana tekstur dari sedimennya terlihat kehitaman. Menurut Palar (2008), secara alamiah logam timbal dapat masuk kedalam perairan melalui pengkristalan udara dengan bantuan air hujan.

Berdasarkan tiga guidelines tentang baku mutu logam berat pada sedimen yang dikeluarkan oleh US-EPA Region V, Kementrian Lingkungan Ontario Canada, dan Swedia (SEPA) menunjukkan adanya perbedaan kriteria dari ketiga baku mutu tersebut. Dari baku mutu US-EPA region $\mathrm{V}$ menunjukkan konsentrasi logam berat Kadmium (Cd) di St. 1 (Muko-muko) masuk dalam katagori terpolusi berat (> $0,006 \mathrm{mg} \mathrm{kg}^{-1}$ ) yaitu sebesar $0,0193 \mathrm{mg}$ $\mathrm{kg}^{-1}$. Sedangkan dari kedua guideline lainnya yaitu: menunjukkan konsentrasi logam kadmium masih dalam ketegori belum terpolusi. Konsentrasi logam timbal 
$(\mathrm{Pb})$ berdasarkan US-EPA Region V pada lokasi St. 2 (Talao Tubo), St. 6 (Muaro Pisang), St. 1 (Muko-muko) dan St. 5 (Bayur) masuk dalam katagori terpolusi berat, namun untuk guidelines lainnya termasuk dalam katagori rendah. Tingginya konsentrasi logam berat pada sedimen di beberapa lokasi secara garis besar berasal dari dua sumber menurut asal proses pembentukannya seperti yang diungkapkan oleh Forstner (1983) yaitu: proses pelapukan batuan (lithogenic) dan aktivitas antropogenik. Whittrnan (1983) lebih lanjut membagi empat proses yang mampu meningkatkan konsentrasi logam berat ke perairan yaitu: 1). Proses pelapukan dari batuan dasar penyusutr partikel sedimen,2). Aktivitas proses industri dan rumah tangga yang melibatkan penggunaan unsur logam berat, 3). Proses leaching dari penumpukan sampah atau limbah padat, dan 4). Hasil ekskresi dari hewan dan tanaman yang mengandung logam berat.

Kondisi secara umum pada sedimen di muara sungai ini cenderung bersifat basa atau memiliki $\mathrm{pH}$ diatas netral diakibatkan oleh konsentrasi sedimen besi $(\mathrm{Fe})$ yang tinggi. Terutama terjadi pada lokasi Talao Tubo yang memiliki pH mencapai 8,69. Tingginya sedimen $\mathrm{Fe}$ untuk perairan tawar akan didukung oleh nutrien tinggi khususnya nutrien $\mathrm{P}$ yang umumnya dihasilkan dari kegiatan pertanian dan perikanan. Kandungan logam lainnya seperti $\mathrm{Cd}, \mathrm{Cr}$ dan $\mathrm{Hg}$ tidak begitu menonjol terlihat di antara stasiun yang ada. Ini membuktikan bahwa danau ini memang cukup lestari dari kegiatan pertambangan dan industri besar lainnya, namun patut diwaspadai karena dari hasil analisi juga sudah terlihat adanya paparan logam berat pada sedimen. Konsentrasi logam merkuri (Hg) pada sedimen tersebar merata di setiap stasiun dengan konsentrasi berkisar 0,0005 $0,0591 \mathrm{mg} \mathrm{kg}{ }^{-1}$. Konsentrasi tertinggi terdapat di St. 4 (Muaro Tanjung) dan terendah pada St. 2 (Talao Tubo) (Gambar 4).Konsentrasi tertinggi pada lokasi ini diduga karena tingginya aktifitas penduduk seperti adanya bengkel-bengkel kendaraan bermotor disekitar sungai serta diduga ada pengaruh dari pupuk pertanian atau perkebunan, namun dugaan ini masih harus penelitian lanjutan mengenai terpaparnya logam merkuri di sedimen ini.

\subsection{Konsentrasi logam berat pada moluska di muara sungai Danau Maninjau.}

Analisis konsentrasi logam berat di muara sungai D. Maninjau ini dilakukan untuk jenis moluska yang menjadi konsumsi masyarakat sekitar, yaitu jenis Corbicula moltkiana atau yang biasa disebut Pensi, Melanoides sp disebut Langkitang dan Bivalvia violacea disebut Lokan oleh masyarakat sekitar. Serta logam berat yang dianalisis meliputi Besi $(\mathrm{Fe})$, timbal $(\mathrm{Pb})$, kadmium $(\mathrm{Cd})$, kromium (Cr) dan merkuri (Hg). Pada Gambar 5 terlihat hasil dari konsentrasi logam berat besi $(\mathrm{Fe})$, timbal $(\mathrm{Pb})$, kadmium $(\mathrm{Cd})$, dan khromium (Cr) pada moluska di muaramuara sungai disekitar D. Maninjau menunjukkan keberadaan logam berat pada setiap moluska yang hampir merata terdapat di semua stasiun. Konsentrasi Fe rata-rata pada moluska berkisar 0,040 $0,948 \mathrm{mg} \mathrm{kg}^{-1}$, dengan konsentrasi tertinggi didapati pada jenis Lokan di St. 1 (Muko-muko) dan terendah pada jenis moluska Pensi di St. 1 (Muko-muko). Konsentrasi $\mathrm{Pb}$ rata-rata pada moluska berkisar $0,002-4,170 \mathrm{mg} \mathrm{kg}^{-1}$, dengan konsentrasi tertinggi didapati pada jenis Pensi di St. 1 (Muko-muko) dan terendah pada jenis moluska Langkitang di St. 1 (Muko-muko). Nilai konsentrasi $\mathrm{Cd}$ ratarata pada moluska berkisar 0,013 - 1,032 $\mathrm{mg} \mathrm{kg}^{-1}$, dengan konsentrasi tertinggi didapati pada jenis Lokan di St. 7 (Pandan) dan terendah pada jenis moluska Langkitang di St. 5 (Bayur). Konsentrasi $\mathrm{Cr}$ rata-rata umumnya berada dibawah limit dari deteksi alat AAS $\left(0,040 \mathrm{mg} \mathrm{kg}^{-}\right.$ $\left.{ }^{1}\right)$, namun masih ditemukan juga dibeberapa lokasi dan jenis moluska yang berkisar $0,047-0,098 \mathrm{mg} \mathrm{kg}^{-1}$ dengan 
konsentrasi tertinggi didapati pada jenis Lokan di St. 7 (Pandan). Sementara pada Gambar 7 untuk konsentrasi Merkuri $(\mathrm{Hg})$ rata-rata pada seluruh moluska berkisar $0,0004-0,1062 \mathrm{mg} \mathrm{kg}^{-1}$, dengan konsentrasi tertinggi didapati pada jenis Lokan di St. 7 (Pandan) dan terendah pada jenis moluska Pensi di St. 3 (Muaro Talao), dan St. 7 (Pandan) serta St. 6 (Muaro pisang) dengan jenis moluska Langkitang. Akumulasi logam timbal dan kadmium untuk seluruh lokasi umumnya ditemukan pada jenis moluska Pensi dan Lokan, namun untuk jenis Langkitang konsentrasi tertinggi terdapat pada logam Besi (Gambar 6).

Plasket dan Potter (1979) menyatakan kandungan logam berat tertinggi umumnya ditemukan pada invertebrata jenis molluska. Akumulasi terjadi karena logam berat pada organisme cenderung membentuk senyawa komplek dengan zat - zat organik yang terdapat dalam tubuh organisme ini sehingga terfiksasi dan tidak diekskresikan oleh organisme yang bersangkutan. Suatu hasil penelitian menunjukkan bahwa akumulasi $\mathrm{Hg}$ pada kerang tropis Saccostrea echinata lebih besar pada suhu air $30{ }^{\circ} \mathrm{C}$ dari pada $20{ }^{\circ} \mathrm{C}$, dan akumulasi tersebut tinggi pada jaringan insang. Diantara logam $\mathrm{Hg}, \mathrm{Cd}$, dan $\mathrm{Pb}$, daya penetrasinya berturut-turut dari yang besar ke yang kecil adalah $\mathrm{Hg}>\mathrm{Cd}>\mathrm{Pb}$ (Denton et al, 1981). Berdasarkan sifat akumulatornya yang tinggi terhadap logam berat maka jenis kerang tersebut banyak digunakan sebagai sampel untuk memonitoring pencemaran logam berat di lingkungan perairan (Darmono, 2001).

Hampir seluruh tepian Danau Maninjau hingga kedalaman tiga meter bahkan hingga lima meter merupakan lokasi penangkapan pensi. Terdapat pusat-pusat penangkapan pensi yang biasanya berhubungan dengan kondisi fisik tepian danau yaitu pada tepian landai dan kedekatan dengan tempat tinggal nelayan. Pola sebaran aktivitas penangkapan pensi umumnya terdapat di bagian utara dari Danau. Maninjau.Berdasarkan data dan informasi yang diperoleh, aktivitas penangkapan pensi memiliki pola yang sangat beragam, baik alat tangkap, metode tangkap, luasan wilayah tangkap maupun hasil tangkap. Hewan air jenis kerangkerangan (bivalva) atau jenis hewan lunak (moluska), baik jenis kerang besar (klam) atau kerang kecil (oister), pergerakannya sangat lambat di dalam air dan biasanya hidup menetap di suatu lokasi tertentu di dasar air. Kandungan logam berat tertinggi umumnya ditemukan pada invertebrata jenis moluska. Akumulasi terjadi karena logam berat pada organisme cenderung membentuk senyawa komplek dengan zat - zat organik yang terdapat dalam tubuh organisme sehingga terfiksasi dan tidak diekskresikan oleh organisme yang bersangkutan. Stadium larva dari jenis kerang ini disebut fase pelagik biasanya peka terhadap terjadinya polusi dalam perairan, kecenderungan kepunahan spesies hewan ini sangat mungkin terjadi. Karena kerang banyak dikonsumsi menyebabkan kerang harus diwaspadai bila dikonsumsi terus-menerus (Darmono, 2001).

\section{Kesimpulan}

1. Kondisi kualitas air di muara sungai disekitar D. Maninjau masih dalam kondisi normal, hanya nilai turbiditas dan TDS yang cukup tinggi.

2. Kandungan Nitrogen pada sedimen tertinggi dijumpai di St. 2 (Talao Tubo), sedangkan kandungan Fosfat tertinggi dijumpai di St. 4 (Muaro Tanjung)

3. Secara keseluruhan lokasi penelitian sudah terpapar oleh logam berat pada sedimen, namun konsentrasi logam berat timbal $(\mathrm{Pb})$ tertinggi dijumpai di St. 6 (Muaro Pisang). Konsentrasi besi (Fe) dan Kadmium (Cd) tertinggi terlihat pada St. 1 (Muko-muko). Sementara konsentrasi merkuri $(\mathrm{Hg})$ 
tertinggi terdapat di St. 4 (Muaro Tanjung).

4. Akumulasi logam timbal $(\mathrm{Pb})$ pada moluska tertinggi ditemukan pada jenis moluska Pensi atau Corbicula moltkiana dan Lokan (Bivalvia violacea) di St. 1 (Muko-muko), sedangkan akumulasi logan cadmium (Cd) paling tinggi ditemukan pada Lokan pada St. 7 (Pandan) dan St. 5 (Bayur). Sementara akumulasi Total khrom (Cr) ditemukan pada jenis moluska Lokan di St. 7 (Pandan)

5. Beban pencemaran pada perairan sungai di sekitar D. Maninjau yang sudah melebihi kemampuan dalam memulihkan diri atau kapasitas asimilasinya adalah TDS, Nitrat dan TP.

\section{Daftar Pustaka}

[APHA] American Public Health Association, [AWWA] American Water Works Association. 2012. Standart Methods for the Examination of Water and Waste Water. $19^{\text {th }}$ Ed. Washington.

Australian and New Zealand Environment and Conservation Council (ANZECC), 2000, ANZECC interim sediment quality guidlines. Report for the Environmental Research Institute of the Supervising Scientist, Sydney, Australia

[Bappeda] Badan Perencanaan Pembangunan Daerah Kabupaten Agam. 2012. Pemantauan dan Evaluasi Kualitas Air Danau Maninjau. Bappeda Kabupaten Agam. Lubuk Basung.

Brusca RC, Brusca GJ. 1990. Invertebrates. Massachusetts: Sinauer.

Connel, D.W. dan GJ.Miller, 1995. Kimia dan Ekotoksikologi Pencemaran, Y. Koestoer (Penerjemah), Universitas Indonesia Press, Jakarta

Darmono, 2001. Logam Berat dalam Sistem Biologi Makhluk Hidup. UIPress. Jakarta

Dojildo, J.R., and G.A. Best. 1992. Chemistry of Water and Water
Pollution. Ellis Horwood Limited. New York.

Fakhrudin, M., H. Wibowo, L. Subehi, dan I. Ridwansyah 2002. Karakterisasi Hidrologi Danau Maninjau Sumatera Barat. Prosiding Seminar Nasional Limnologi. Pusat Penelitian Limnologi - LIPI.

Jorgensen, S.E., and R.A. Vollenweiden. 1989. Guedelines of Lakes Management: Principles of Lakes Management Vol 1. International Lake Environment Foundation. Shiga-Japan.

Kumurur, V.A. 2002. Aspek strategis pengelolaan Danau Tondano secara terpadu. Ekoton 2 (1) : 73-80.

Metcalf dan Eddy. 2002. Wastewater Engineering, Treatment and Reuse. Volume 1. 4th Edition. Revised by George Tchobanoglous, Franklin L. Burton and H. David Stensel. Mc Graw Hill Higher Education

Menteri Negara Lingkungan Hidup. Keputusan Menteri Negara Lingkungan Hidup Republik Indonesia Nomor 115/2003 Tentang Pedoman Penentuan Status Mutu Air. Jakarta : KLH.

Rump, H.H. 1999. Laboratory Manual fot the Examinaton of Water, Waste Water and Soil. $3^{\text {rd }}$ completely revised edition. English translation by Elisabeth j. Grayson. WileyVHC. Weinheim. Germany

Suwanto, A., T.N. Harahap, H. Manurung, W.C. Rustadi, S.R. Nasution, I N.N. Suryadiputra, dan I. Sualia. 2011. Profil 15 Danau Prioritas Nasional. Kementerian Lingkungan Hidup. $148 \mathrm{p}$.

Walukow F A, Setiyanto D D, Kholil, Soedarma D 2008. Analisis beban pencemaran dan kapasitas asimilasi Danau Sentani, Papua, sebagai upaya konservasi lingkungan perairan. Berita Biologi 9(3): 229-236. 


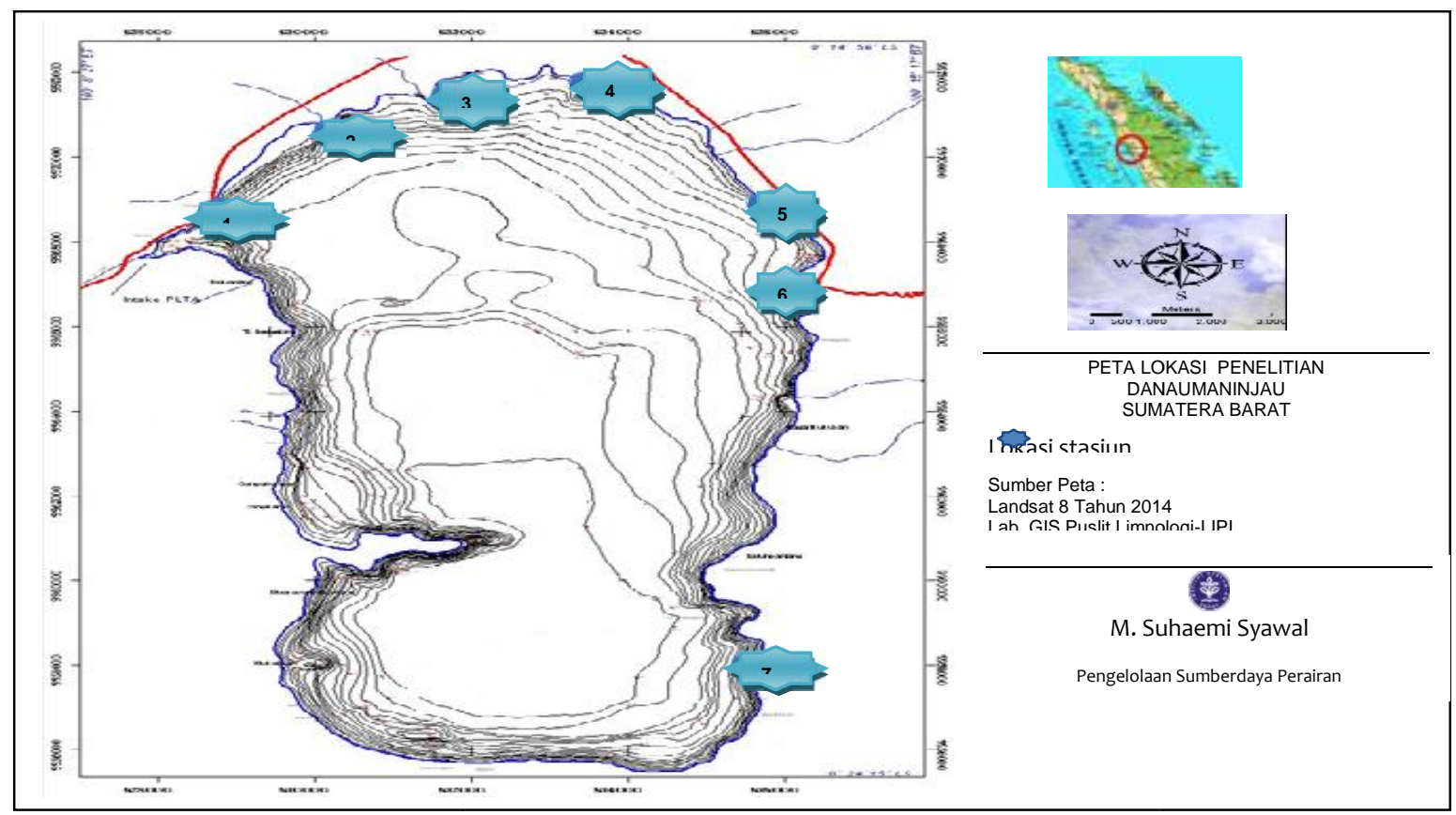

Gambar 1. Lokasi dan titik pengambilan contoh di Danau Maninjau Keterangan : St. 1 Muko-Muko (MM); St. 2 Talao Tubo (TT); St. 3 Muaro Talao (MTa); St. 4 Muaro Tanjung (MTj); St. 5 Bayur (Ba); St. 6 Muaro Pisang (MP); St. 7 Pandan $(\mathrm{Pa})$

Tabel 1 Karakteristik lokasi dan titik sampling di Danau Maninjau

\begin{tabular}{|c|c|c|}
\hline Lokasi & Posisi & Keterangan \\
\hline Muko-Muko (St. 1) & $\begin{array}{l}00^{\circ} 17,353^{\prime} \mathrm{LS} \\
100^{\circ} 08,967^{\prime} \mathrm{BT}\end{array}$ & $\begin{array}{l}\text { - } \text { Terdapat intake PLTA } \\
\text { - Outlet Danau Maninjau } \\
\text { - Kawasan wisata } \\
\text { - } \text { banyak KJA }\end{array}$ \\
\hline Talao Tubo (St. 2) & $\begin{array}{l}00^{\circ} 15,853^{\prime} \mathrm{LS} \\
100^{\circ} 10,184 \mathrm{BT}\end{array}$ & $\begin{array}{l}\text { - Persawahan } \\
\text { - Banyak KJA } \\
\text { - Pemukiman padat penduduk }\end{array}$ \\
\hline Muaro Talao (St. 3) & $\begin{array}{l}00^{\circ} 15,574^{\prime}, \mathrm{LS} \\
100^{\circ} 10,951 \text { ' BT }\end{array}$ & $\begin{array}{l}\text { - Terdapat persawahan } \\
\text { - KJA sedikit }\end{array}$ \\
\hline Muara Tanjung (St. 4) & $\begin{array}{l}00^{\circ} 15,636^{\prime} \mathrm{LS} \\
100^{\circ} 10,810 \mathrm{BT}\end{array}$ & $\begin{array}{l}\text { - Persawahan/perkebunan } \\
\text { - Rumah pendukuk sedikit } \\
\text { - Banyak KJA }\end{array}$ \\
\hline Bayur (St. 5) & $\begin{array}{l}00^{\circ} 16,317^{\prime} \mathrm{LS} \\
100^{\circ} 12,840 \mathrm{BT}\end{array}$ & $\begin{array}{l}\text { - Pusat keramba jaring apung } \\
\text { - pasar tradisional } \\
\text { - banyak KJA } \\
\text { - Pemukiman padat penduduk } \\
\text { - Hotel dan bengkel kendaraan }\end{array}$ \\
\hline Muaro Pisang (St. 6) & $\begin{array}{l}00^{\circ} 16,4266^{\prime} \mathrm{LS} \\
100^{\circ} 12,928, \mathrm{BT}\end{array}$ & $\begin{array}{l}\text { - Terdapat pasar tradisonal } \\
\text { - Pemukiman padat penduduk } \\
\text { - banyak KJA }\end{array}$ \\
\hline Pandan (St. 7) & $\begin{array}{l}00^{\circ} 22,506^{\prime} \mathrm{LS} \\
100^{\circ} 13,136 \mathrm{BT}\end{array}$ & $\begin{array}{l}\text { - Terdapat pasar tradisonal } \\
\text { - Pemukiman padat penduduk } \\
\text { - banyak KJA }\end{array}$ \\
\hline
\end{tabular}


Tabel 2. Nilai kisaran dan range kondisi fisika air hasil pengukuran dilapangan

\begin{tabular}{|c|c|c|c|c|c|c|c|}
\hline Lokasi & $\begin{array}{c}\text { Suhu Air } \\
{ }^{\circ} \mathrm{C}\end{array}$ & $\mathrm{pH}$ & $\begin{array}{c}\text { Kondukti } \\
\mathrm{mS} / \mathrm{cm}\end{array}$ & $\begin{array}{l}\text { ORP } \\
\mathrm{mV}\end{array}$ & $\begin{array}{c}\mathrm{DO} \\
\mathrm{mg} \mathrm{L}^{-1}\end{array}$ & $\begin{array}{c}\text { Turbiditas } \\
\text { NTU }\end{array}$ & $\begin{array}{l}\text { TDS } \\
\mathrm{mg} \mathrm{L}^{-1}\end{array}$ \\
\hline $\begin{array}{l}\text { Muko-Muko } \\
\text { (St. 1) }\end{array}$ & $\begin{array}{c}23.26 \pm 0.77 \\
\quad(1.41)\end{array}$ & $\begin{array}{c}7.44 \pm 0.15 \\
(0.28)\end{array}$ & $\begin{array}{l}0.05 \pm 0.03 \\
\quad(0.06)\end{array}$ & $\begin{array}{c}124.8 \pm 15.0 \\
(30)\end{array}$ & $\begin{array}{c}7.61 \pm 0.4 \\
(0.8)\end{array}$ & $\begin{array}{c}85.8 \pm 31.7 \\
\quad(63.4)\end{array}$ & $\begin{array}{c}69.7 \pm 69.3 \\
(134.8)\end{array}$ \\
\hline $\begin{array}{l}\text { Talao Tubo } \\
\text { (St. 2) }\end{array}$ & $\begin{array}{c}21.87 \pm 1.05 \\
(2.11)\end{array}$ & $\begin{array}{c}8.69 \pm \\
0.16 \\
(0.29)\end{array}$ & $\begin{array}{l}0.12 \pm 0.02 \\
\quad(0.04)\end{array}$ & $\begin{array}{c}193.0 \pm \\
19.3 \\
(37.2)\end{array}$ & $\begin{array}{c}6.97 \pm 0.42 \\
\quad(0.83)\end{array}$ & $\begin{array}{c}88.3 \pm 22.5 \\
\quad(45)\end{array}$ & $\begin{array}{l}58.0 \pm 18.6 \\
(36.05)\end{array}$ \\
\hline $\begin{array}{l}\text { Muaro Talao } \\
\text { (St. 3) }\end{array}$ & $\begin{array}{c}22.23 \pm 2.23 \\
(4.11)\end{array}$ & $\begin{array}{c}7.55 \pm \\
0.13 \\
(0.26)\end{array}$ & $\begin{array}{l}0.06 \pm 0.02 \\
\quad(0.04)\end{array}$ & $\begin{array}{c}164.2 \pm \\
28.1 \\
(56)\end{array}$ & $\begin{array}{c}6.9 \pm 0.14 \\
(0.36)\end{array}$ & $\begin{array}{c}93.47 \pm 26.5 \\
(162)\end{array}$ & $\begin{array}{l}43.2 \pm 20 \\
\quad(20)\end{array}$ \\
\hline $\begin{array}{l}\text { Muaro } \\
\text { Tanjung } \\
\text { (St. 4) }\end{array}$ & $\begin{array}{c}21.29 \pm 0.49 \\
(0.97)\end{array}$ & $\begin{array}{c}7.98 \pm \\
0.07 \\
(0.13)\end{array}$ & $\begin{array}{l}0.14 \pm 0.02 \\
\quad(0.04)\end{array}$ & $\begin{array}{c}178.3 \pm \\
38.3 \\
(73.3)\end{array}$ & $\begin{array}{c}8 \pm 0.18 \\
(0.36)\end{array}$ & $\begin{array}{c}183.6 \pm 85.4 \\
(162)\end{array}$ & $\begin{array}{c}63.7 \pm 20 \\
\quad(40)\end{array}$ \\
\hline $\begin{array}{l}\text { Bayur } \\
\text { (St. 5) }\end{array}$ & $\begin{array}{c}22.21 \pm 0.85 \\
\quad(1.69)\end{array}$ & $\begin{array}{l}7.86 \pm \\
0.23 \\
(0.45)\end{array}$ & $\begin{array}{l}0.07 \pm 0.02 \\
\quad(0.03)\end{array}$ & $\begin{array}{c}152.7 \pm \\
51.0 \\
(92.5)\end{array}$ & $\begin{array}{c}6.9 \pm 0.92 \\
(1.59)\end{array}$ & $\begin{array}{c}93.5 \pm 39.9 \\
(69.1)\end{array}$ & $\begin{array}{l}43.2 \pm 12.8 \\
\quad(22.5)\end{array}$ \\
\hline $\begin{array}{l}\text { Muaro Pisang } \\
\text { (St. 6) }\end{array}$ & $\begin{array}{c}22.28 \pm 1.22 \\
\quad(2.16)\end{array}$ & $\begin{array}{l}7.65 \pm \\
0.12 \\
(0.22)\end{array}$ & $\begin{array}{l}0.04 \pm 0.01 \\
\quad(0.01)\end{array}$ & $\begin{array}{c}111.3 \pm \\
34.6 \\
(69)\end{array}$ & $\begin{array}{c}7.99 \pm 0.29 \\
(0.58)\end{array}$ & $\begin{array}{c}127.4 \pm 76 . \\
(136.2)\end{array}$ & $\begin{array}{c}28.6 \pm 4.38 \\
(8.5)\end{array}$ \\
\hline $\begin{array}{l}\text { Pandan } \\
\text { (St. 7) }\end{array}$ & $\begin{array}{c}21.03 \pm 0.3 \\
(0.55)\end{array}$ & $\begin{array}{c}7.64 \pm \\
0.21 \\
(0.41)\end{array}$ & $\begin{array}{c}0.03 \pm 0.002 \\
(0.004)\end{array}$ & $\begin{array}{c}202.3 \pm \\
14.2 \\
(27.5)\end{array}$ & $\begin{array}{c}8.46 \pm 0.02 \\
\quad(0.04)\end{array}$ & $\begin{array}{c}326.4 \pm 178.8 \\
(330.2)\end{array}$ & $\begin{array}{l}22 \pm 1 \\
(2)\end{array}$ \\
\hline Rata-rata & $\begin{array}{c}22.02 \pm 1.19 \\
(4.11)\end{array}$ & $\begin{array}{c}7.83 \pm \\
0.42 \\
(1.54)\end{array}$ & $\begin{array}{l}0.08 \pm 0.04 \\
\quad(0.14)\end{array}$ & $\begin{array}{c}160.9 \pm \\
41.5 \\
(136.7)\end{array}$ & $\begin{array}{l}7.67 \pm 0.66 \\
\quad(2.64)\end{array}$ & $\begin{array}{c}138.6 \pm 112.1 \\
(425.3)\end{array}$ & $\begin{array}{c}48.9 \pm 29.7 \\
\quad(134.8)\end{array}$ \\
\hline
\end{tabular}

Keterangan : Data merupakan angka rata-rata pengukuran Maret - September 2015 pada kedalaman $20 \mathrm{~cm}$ dibawah permukaan air; angka didalam kurung (..) merupakan range dari setiap parameter

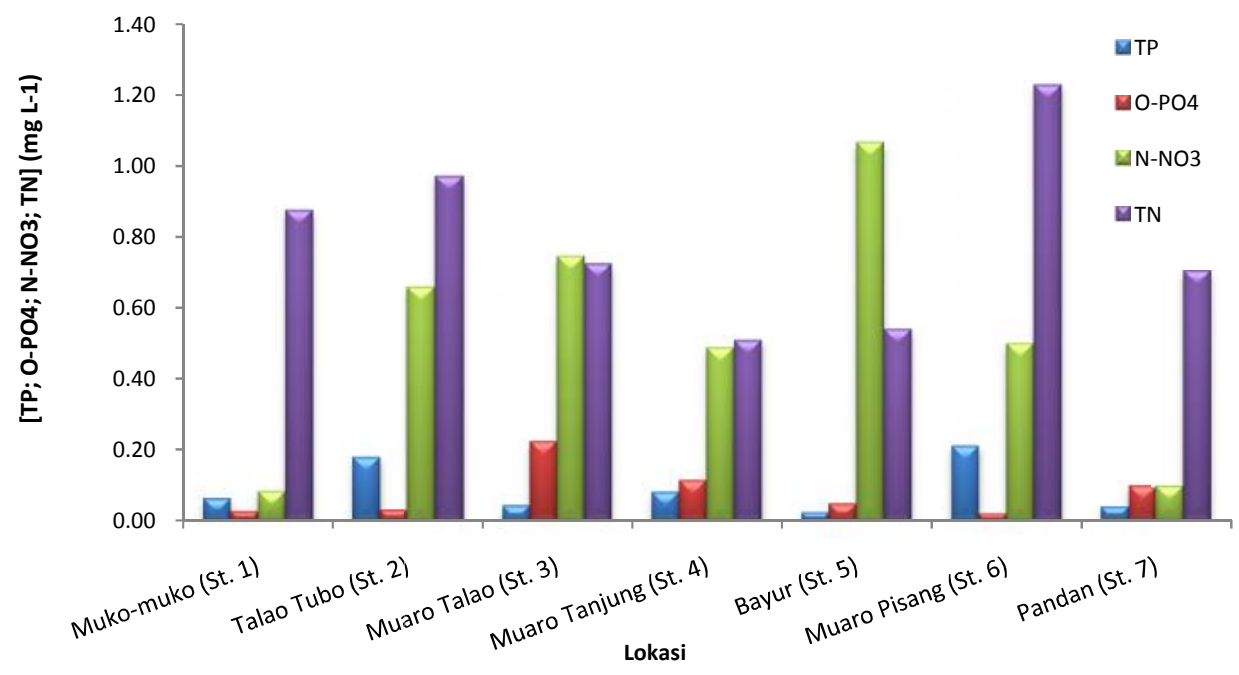

Gambar 2. Konsentrasi Total Phospat (TP), Ortofosfat $\left(\mathrm{O}-\mathrm{PO}_{4}\right)$, Nitrat $\left(\mathrm{N}-\mathrm{NO}_{3}\right)$ dan Total Nitrogen (TN) di muara sungai sekitar Danau Maninjau. 


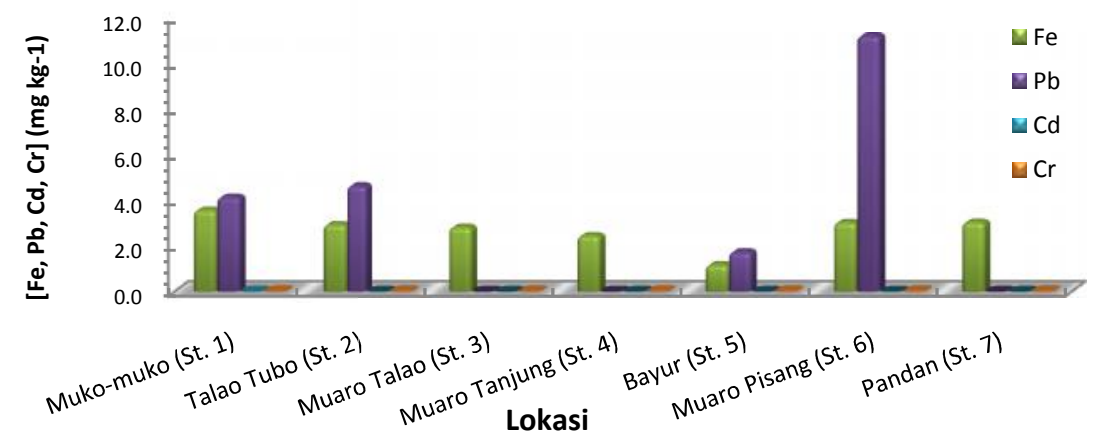

Gambar 3. Konsentrasi logam berat pada sedimen di muara sungai sekitar Danau Maninjau.

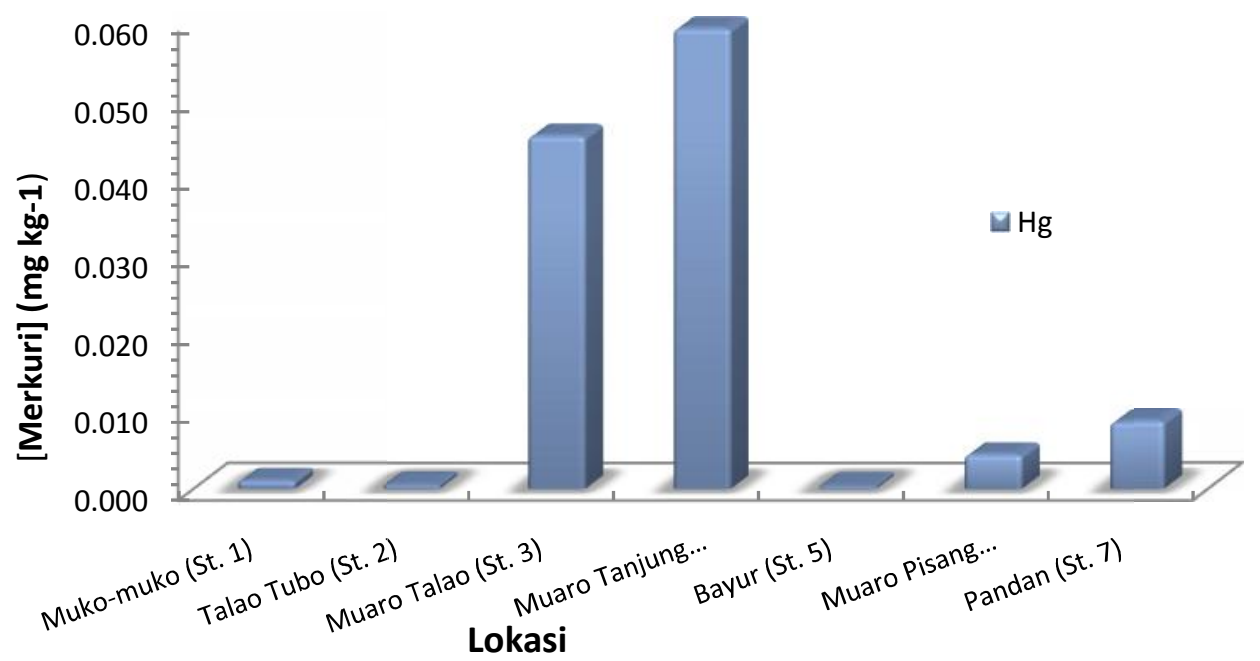

Gambar 4. Konsentrasi logam Merkuri (Hg) pada sedimen di muara sungai sekitar Danau Maninjau. 


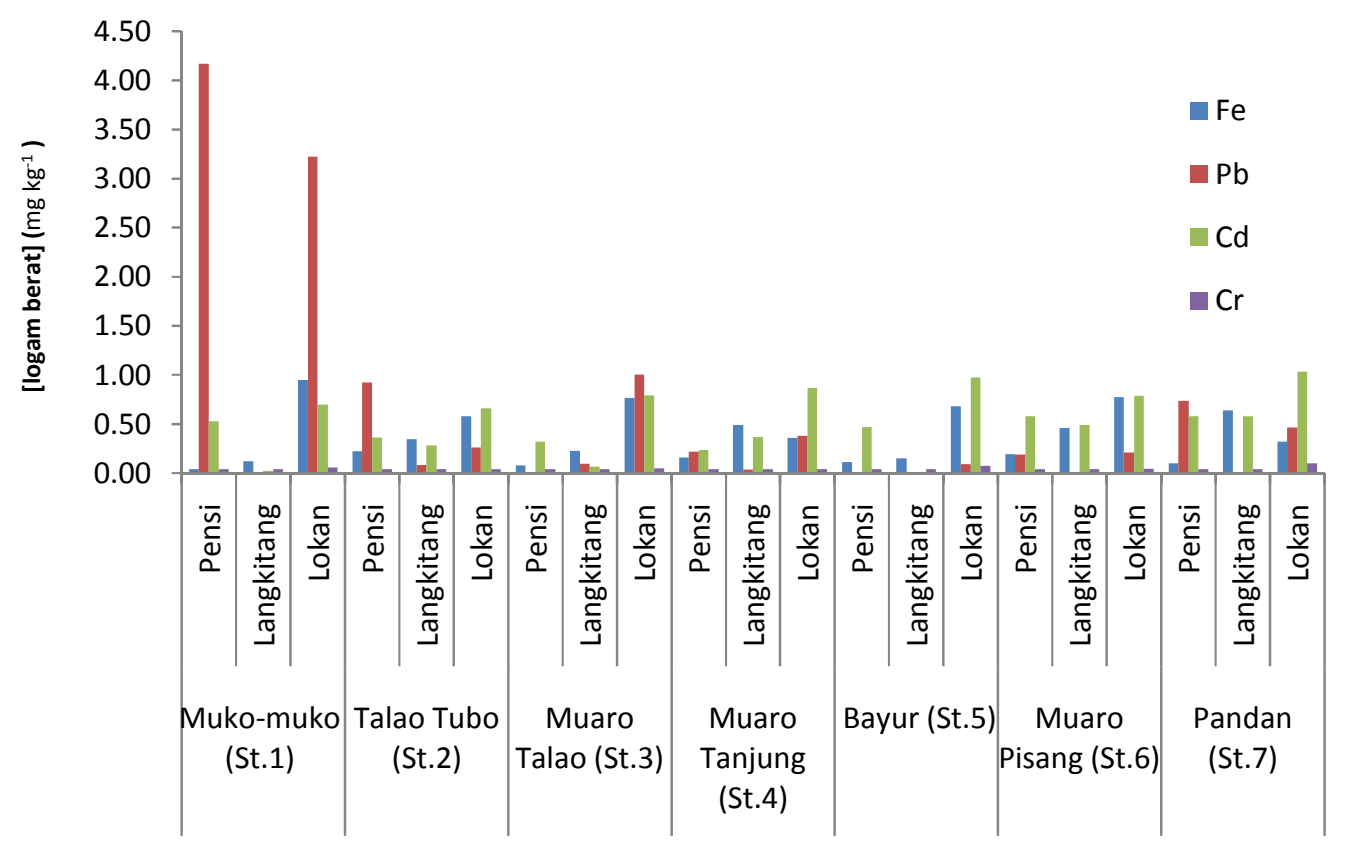

(Lokasi dan jenis moluska)

Gambar 5. Konsentrasi logam berat Besi (Fe), Timbal (Pb), Kadmium (Cd), dan Khromium (Cr) pada moluska di muara sungai D. Maninjau.

Keterangan : Pensi (Corbicula moltkiana, Prime 1878); Langkitang (Melanoides sp) dan Lokan (Bivalvia violacea)

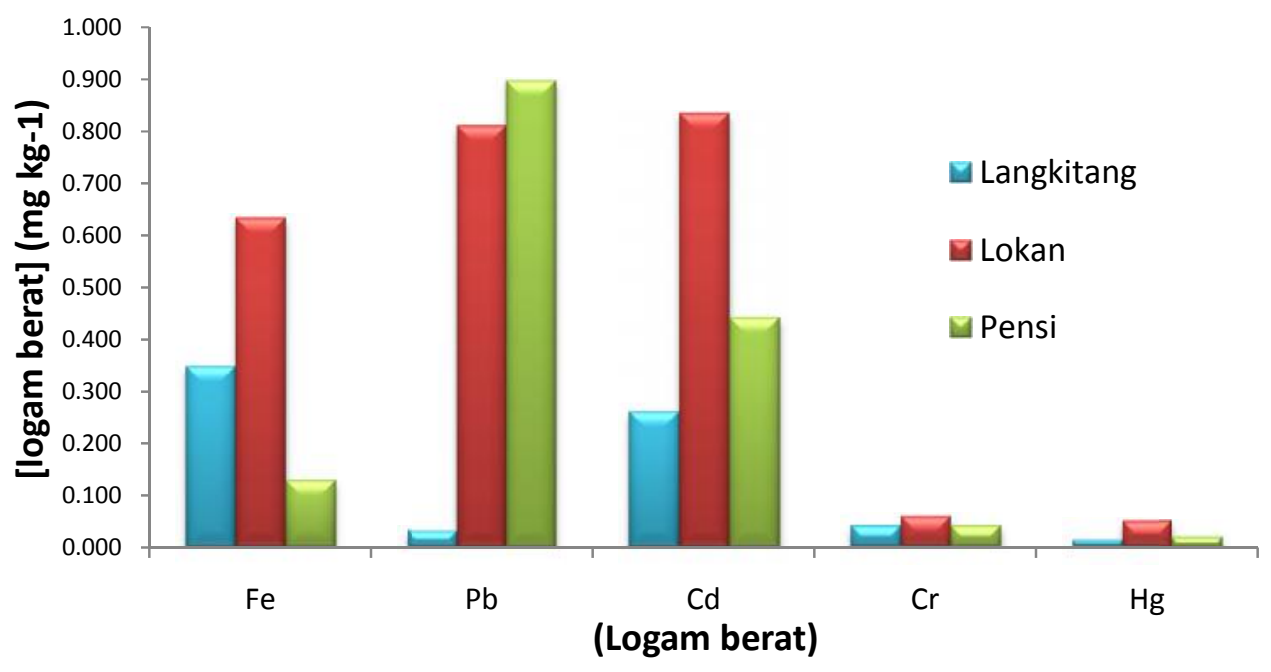

Gambar 6. Konsentrasi logam berat besi (Fe), timbal $(\mathrm{Pb})$, kadmium $(\mathrm{Cd})$, dan kromium $(\mathrm{Cr})$ pada moluska di muara sungai Danau Maninjau. 
Keterangan : Pensi (Corbicula moltkiana, Prime 1878); Langkitang (Melanoides sp) dan Lokan (Bivalvia violacea)

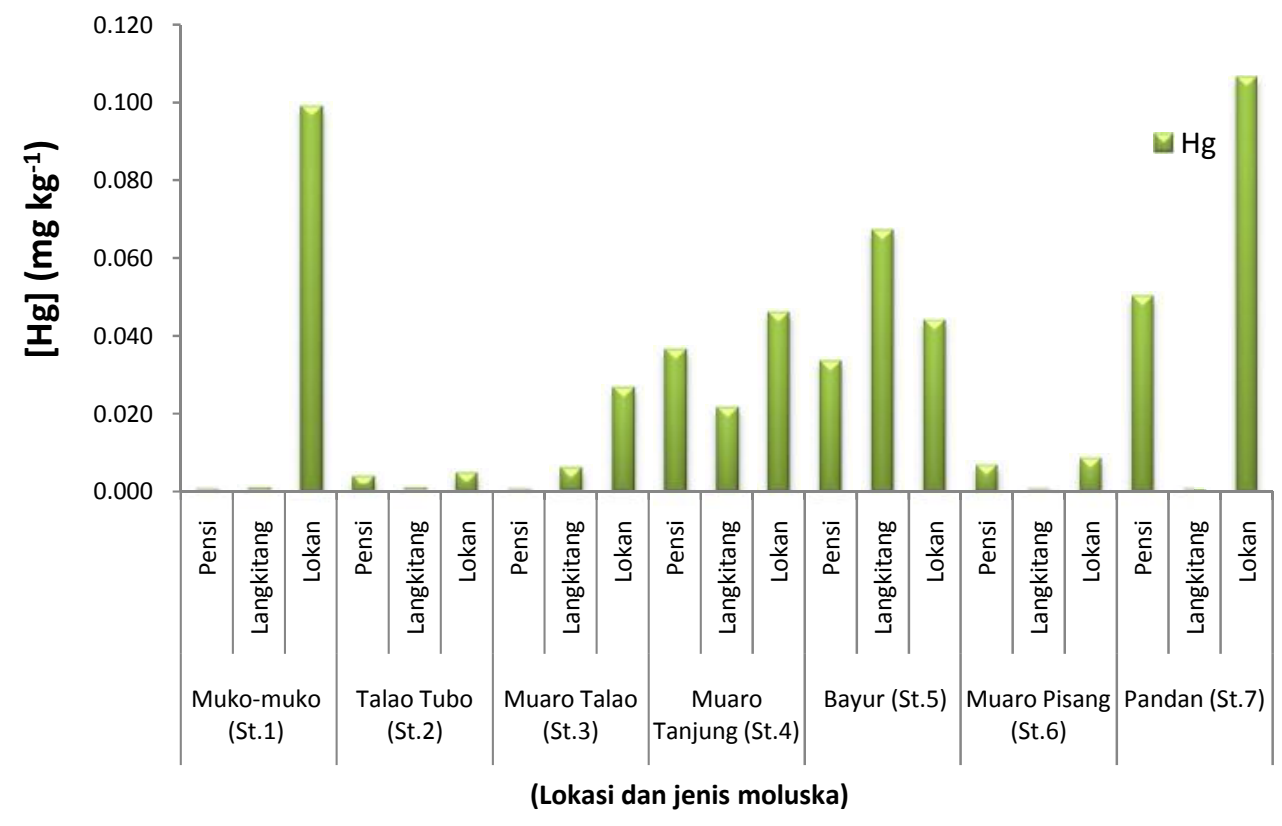

Gambar 7. Konsentrasi Merkuri (Hg) pada moluska di muara sungai D. Maninjau.

Keterangan: Pensi (Corbicula moltkiana, Prime 1878); Langkitang (Melanoides sp) dan Lokan (Bivalvia violacea) 